\title{
Variability in Soil Aggregation and Depth Distribution of Aggregate Associated Organic Carbon Fractions Relevance to Different Agricultural Practices in Agro-ecosystems of North-West India: A Review
}

\author{
S. P. Singh ${ }^{1 *}$, R. K. Naresh ${ }^{2}$, Yogesh Kumar ${ }^{1}$, Snehdeep ${ }^{1}$ and Rahul Inder Navsare ${ }^{1}$ \\ ${ }^{1}$ Department of Soil Science \& Agricultural Chemistry, ${ }^{2}$ Department of Agronomy, Sardar \\ Vallabhbhai Patel University of Agriculture \& Technology, Meerut, (UP), India \\ *Corresponding author
}

\section{Keywords \\ Soil organic carbon fractions, Soil aggregate, Stratification ratio, Conservation tillage, Carbon stocks}

\section{Article Info}

Accepted:

18 August 2020 Available Online: 10 September 2020

\section{A B S T R A C T}

Soil aggregates and organic matter are considered to be important indicators of soil quality. The objective of this review study was to determine agricultural practices effects on the distribution of soil organic carbon (SOC) associated with aggregate-size fractions. Depth distribution of soil organic carbon (SOC) fractions depends on the efficiency of agro- technical managements. The SOC stocks to $1-\mathrm{m}$ depth were $172.3 \mathrm{Mg} \mathrm{C}^{-1}$ under Forest and the lowest $89.3 \mathrm{Mg} \mathrm{C}^{-1}$ under home-garden. No significant differences were noted in SOC within the silt + clay fraction $(<53 \mu \mathrm{m})$ beyond $60 \mathrm{~cm}$ depth under Forest and other shaded AFS. Moreover, depth, aggregate size and treatment had significant interaction effects on SOC stocks. The reports show that deep rooted, crop-based systems, have higher total soil $\mathrm{C}$ stocks and more $\mathrm{C}$ in the smallest $(<53 \mu \mathrm{m})$ soil fractions indicating the recalcitrant (longer-term storage) nature of $\mathrm{C}$ and implying consequent ecosystem benefit of reduced chances for soil $\mathrm{C}$ release back to the atmosphere. Moreover, the mean stratification ratio (SR) (i.e. a ratio of the concentrations of SOC in the soil surface to those in a deeper layer) of SOC for 0-5:5-10, 10-15, 15-20, 20-25 and 25-30 $\mathrm{cm}$ were found higher (> 2) under CA practices compared to intensive tillage-based conventional agricultural practice. The fractions of aggregates, aggregate SOC and aggregate EOC in grassland and forestland were generally higher than those in farmland. Furthermore, because conventional cultivation destroyed aggregates, the dominant aggregate size fractions were $<0.5 \mathrm{~mm}$ for farmland and $>0.5 \mathrm{~mm}$ for other land uses. Compared to the corresponding values in farmland, the mean weight diameter (MWD) in forestland and grassland increased by $808 \%-417 \%$, and the stability ratio of water-stable aggregate (WSAR) increased by $920 \%-553 \%$. Aggregate formation and its dominant size fraction were associated closely with its carbon fractions. SOC and EOC in farmland tended to be concentrated in smaller-sized aggregates, whereas SOC and EOC under other land uses tended to concentrate in larger-sized aggregates. The MBC concentration was the highest in minimum tillage (MT) system, at 15 to $30-\mathrm{cm}$ depth and PMC concentration was highest with MT at $45-60 \mathrm{~cm}$. The highest DOC was at 0 to $15-\mathrm{cm}$ depth. The highest stratification ratio (SR) of PMC was under MT with at 0-15:15-30 and POC was under tine cultivator (TC) and moldboard plow (MP) at depths of 0-15:45$60 \mathrm{~cm}$. The highest SR for DOC was under MP at 0-15:45-60 cm and $\mathrm{HCl}$ insoluble C was under MT at 0-15:45-60. In broad- spectrum, labile organic fractions revealed differential sensitivity, and POC stocks are also a sensitive indicator to detect the shortmanagement effects. 


\section{Introduction}

On a global scale, soil organic carbon (SOC) reservoir is approximately twice as large as that of the atmosphere, and approximately three times that resides within the vegetation (Smith et al., 2008). Even subtle changes in the overall mass of global SOC pools could trigger immense fluctuation in the concentration of $\mathrm{CO}_{2}$ in the ambient atmosphere. One potential modification of the SOC pool may occur due to the changes in microbial decomposition of organic matter in the soil. The stability of SOC against microbial degradation is thought to be contingent on various interactions between SOC chemistry, soil climate, soil fauna, and soil structure (Davidson and Janssens, 2006). Of these factors, the effects of soil structure and/or aggregation on SOC dynamics remain one of the least understood, particularly in natural ecosystems. Water-stable aggregation rate has been recognized as one of the standard features of soil quality that affects SOC dynamics (Pulleman et al., 2005; Bu et al., 2012).

Soil organic matter may be protected from temperature fluctuations via microaggregation $(53-250 \mu \mathrm{m})$ within macroaggregates (250-2000 $\mu \mathrm{m})$, physical binding with soil clay and silt particles, and the biochemical formation of recalcitrant SOC compounds (Plante et al., 2011).

Conventional tillage practices induce the disruption of soil aggregates due to soil disturbance by plowing and removing crop residues from the field, as has been reported widely (Andruschkewitsch et al., 2014). The disruption of soil aggregates results in enhanced SOC decomposition and transformation rates (Zotarelli et al., 2007). Some studies have reported that conservation tillage can improve SOC stabilization (Nath and Lal, 2017). Compared with conventional tillage, which can accelerate the regeneration of macro-aggregates, conservation tillage can yield greater macro-aggregate content and sequester more SOC in agricultural land (Alvaro Fuentes et al., 2008). However, most studies of the effects of tillage and straw retention on soil aggregates have focused on plowing depth $(0-20 \mathrm{~cm})$ (Liu et al., 2015), while deep soil degradation is becoming a serious limitation to crop yield and soil quality (Hartmann et al., 2008). Accordingly, it is necessary to conduct studies of deep soil (Zhu et al., 2017).

Subsoil C storage may be achieved by increasing $\mathrm{C}$ inputs to deep soil layers, decreasing the rate of SOC mineralization, or a combination of both. Carbon inputs are delivered to deep layers through root growth, bioturbation or mechanical incorporation of surface litters, and transport of dissolved organic C from surface layers (Rumpel and KögelKnabner, 2011). Management practices designed to increase subsoil $\mathrm{C}$ stocks have focused primarily on increasing root $\mathrm{C}$ inputs at depth (Paustian et al., 2016) for at least three reasons. First, the similarity of root and SOC vertical distributions across biomes suggests that root $\mathrm{C}$ inputs are a dominant control on deep SOC stocks. Second, rootderived $\mathrm{C}$ has a longer residence time than shoot-derived $\mathrm{C}$ potentially because it is more biochemically resistant to mineralization (Ahmad et al., 2014) and more likely to become protected through occlusion within soil aggregates than is shoot $\mathrm{C}$ (Kong and Six, 2010). And third, variation exists in root system size and depth within and among crop species, which can potentially be exploited for deep C delivery (Lynch and Wojciechowski, 2015). A better understanding of the impact of agricultural management on root inputs, and the effects of enhanced root inputs on subsoil $\mathrm{C}$ storage, will be required if deeprooting cropping systems are to be widely adopted for C storage (Paustian et al., 2016). 
The objectives of the review study were to ascertain the effects of long-term conservation tillage and residue retention on: (1) aggregate distribution and stability in the vertical direction in soil; and (2) variations in aggregate-associated and sub-fractionassociated OC in a deep soil. It was hypothesized that: (1) compared to conventional tillage, conservation tillage would yield more SOC and stable macroaggregates in the deep soil layer; (2) conservation tillage would result in more SOC in soil macro-aggregates than conventional tillage; and (3) mineralassociated OC (mSOC) was the main form of SOC accumulated.

\section{Effect of Agricultural Practices on SOC and EOC}

Tan et al., (2007) revealed that across soil depths, significant difference was observed among treatments with respect to SOC concentration. The light fraction accounted for $12.0 \%, 10.8 \%$ and $5.7 \%$ of the total soil mass in forest, NT and CT soils, respectively. Averaged across all treatments, light fraction decreased with depth from $11 \%$ in the $0-5 \mathrm{~cm}$ to $8.8 \%$ in the $10-20 \mathrm{~cm}$ depth. In the CT soil, however, variation with depth was minor probably due to homogenization and mixing effect of plowing. A higher mass proportion of light fraction was observed by Wander and Traina (1996), which may be due to greater light fraction recovery resulting from the use of a higher density SPT solution $\left(1.85 \mathrm{~g} \mathrm{~mL}^{-1}\right.$ versus $\left.1.65 \mathrm{~g} \mathrm{~mL}^{-1}\right)$. Chen et al., (2016) reported that the SOC concentration decreased with soil depth. In both 0-10 and 10-20 cm, the SOC concentration in the RP treatment was significantly greater than that in the other four treatments, yet no significant differences were found among the other four. In $20-30 \mathrm{~cm}$, there were in general no significant differences among all the rotation systems.
Zheng et al., (2018) reported that across treatments, aggregate-associated $\mathrm{C}$ at a depth of $0-10 \mathrm{~cm}$ was higher in the NT and ST treatments than in the MP and CT treatments. The advantage of the NT treatment weakened with soil depth, while the amount of aggregate-associated $\mathrm{C}$ remained higher for the ST treatment. There were more macroaggregates in the ST and NT treatments than in the MP and CT treatments, while the MP and CT treatments had more microaggregates. The sum of macro-aggregate contributing rates for soil organic $\mathrm{C}$ (SOC) was significantly superior to that of the microaggregates. Mahajan et al., (2019) reported that the increased SOC stock in the surface 50 $\mathrm{kg} \mathrm{m}^{-2}$ under ZT and PRB was compensated by greater SOC stocks in the 50-200 and 200$400 \mathrm{~kg} \mathrm{~m}^{-2}$ interval under residue retained, but SOC stocks under CT were consistently lower in the surface $400 \mathrm{~kg} \mathrm{~m}^{-2}$.

Zou et al., (2016) also found that the soil EOC content ranged from $7.98-11.23 \mathrm{~g} \mathrm{~kg}^{-1}$ for $S_{400}, 8.80-13.47 \mathrm{~g} \mathrm{~kg}^{-1}$ for $S_{800}, 7.92-$ $10.02 \mathrm{~g} \mathrm{~kg}^{-1}$ for $S_{1200}$ and $7.58-9.42 \mathrm{~g} \mathrm{~kg}^{-1}$ for $\mathrm{S}_{1600}$. The EOC contents in the $\mathrm{S}_{800}$ treatment were the highest, and the EOC contents in the CK were the lowest at each soil depth. Some appreciable differences were observed between the straw return in the different treatments, which decreased in the following order: $\mathrm{S}_{800}>\mathrm{S}_{400}>\mathrm{S}_{1200}>\mathrm{S}_{1600}>\mathrm{CK}$ (Fig. 1a). The deep soil (depth of $20-40 \mathrm{~cm}$ ) had the lowest EOC content compared with the other two depths. In the control treatment, the soil EOC decreased as the soil depth increased from $0-10 \mathrm{~cm}$ to $10-20 \mathrm{~cm}$. In the straw return treatments, the soil EOC was higher at $10-20 \mathrm{~cm}$ than at $0-10 \mathrm{~cm}$. However, the soil LFOC in the different straw return treatments ranged from 223.12-280.37 $\mathrm{mg} \mathrm{kg}^{-1}$ for $S_{400}, 235.67-300.32 \mathrm{mg} \mathrm{kg}^{-1}$ for $\mathrm{S}_{800}, 233.78-301.32 \mathrm{mg} \mathrm{kg}^{-1}$ for $\mathrm{S}_{1200}$, and 218.44-268.77 mg kg-1 for $S_{1600}$. The ranges of soil LFOC in all treatments decreased as 
follows: $\mathrm{S}_{1200}>\mathrm{S}_{800}>\mathrm{S}_{400}, \mathrm{CK}>\mathrm{S}_{1600}$ at 0-10 $\mathrm{cm}, \mathrm{S}_{800}, \mathrm{~S}_{1200}>\mathrm{CK}, \mathrm{S}_{400}>\mathrm{S}_{1600}$ at $10-20 \mathrm{~cm}$, and $S_{800}, S_{1200}>S_{400}>S_{1600}>C K$ at $20-40$ cm (Fig. 1b).

Conforti et al., (2016) observed that the maximum value $\left(214.5 \mathrm{Mg} \mathrm{ha}^{-1}\right)$ of SOC stock was observed in the A horizons accounting for about $30 \%$ of the estimated total SOC stock along soil profile. The significant lowest values were recorded in the organic horizon, which stored approximately $2 \%$ of total SOC stock. Vertical distribution of SOC stock highlighted that even though there was less variability in SOC stock across A-Bw horizons, a significant decrease with depth was observed towards BC and especially $\mathrm{Cr}$ layers. The results revealed that the sampling thickness of $20 \mathrm{~cm}$ for $\mathrm{Cr}$ layers can be considered reliable because of the above quoted decreasing trend of SOC stock in depth. This behavior is consistent with the evidence that N96\% of SOC was stored in the overlying soil horizons. In addition, a similar decreasing trend of the weathering degree of the parent rock down-profile suggests a possible corresponding decrease in the storage capacity of SOC. FB. At $0-5 \mathrm{~cm}$ and $5-10 \mathrm{~cm}$ depths in PRB, the concentration of TOC was significantly higher than the corresponding depths in FB and $\mathrm{TT}(\mathrm{PRB}>\mathrm{FB}>\mathrm{TT})$. However, at 10-20 and 20-40 cm, no significant differences were observed in TOC concentration between treatments. At 40-60 $\mathrm{cm}$, TT tillage had the highest TOC concentration $\left(5.5 \mathrm{gkg}^{-1}\right)$ which differed significantly from $\mathrm{FB}\left(4.6 \mathrm{gkg}^{-1}\right)$; the trend in TOC concentration was TT $>$ PRB $>$ FB.

Zhao et al., (2014) also found that the contents of SOC, TN, POC and LOC responded differently as the change of soil depth (Fig. 2a). In all land use types, contents of SOC, TN, POC and LOC in top soil (0-10 $\mathrm{cm})$ were $3.26-7.86 \mathrm{gkg}^{-1}, 0.39-0.72 \mathrm{gkg}^{-1}$, $0.65-1.31 \mathrm{gkg}^{-1}$ and $0.76-1.07 \mathrm{gkg}^{-1}$, respectively, which were significantly higher than other soil layers. The contents of SOC, TN, POC and LOC decreased significantly in soil depth of 10-40 cm while the decreases trended to be flatter in subsoil $(40-100 \mathrm{~cm})$. Additionally, the differences in contents of SOC, TN, POC and LOC in deep subsoil $(100-200 \mathrm{~cm})$ were negligible. The differences in contents of SOC, TN, POC and LOC between three types (RP, CK and $\mathrm{AB}$ ) and $\mathrm{SC}$ are shown in Fig. 2b. The differences in SOC, TN, POC and LOC of RP and SC in soil depths of $0-10 \mathrm{~cm}$ and $100-200 \mathrm{~cm}$ were significantly higher than that between other land use types and SC. The differences in SOC and TN of RP were $33.78 \%$ and $45.97 \%$ larger than that of $\mathrm{CK}$ and $54.13 \%$ and $67.28 \%$ larger than that of $\mathrm{AB}$ in soil depth of $0-10 \mathrm{~cm}$ while the differences in POC and LOC were $32.8 \%, 54.0 \%$ higher than that of CK, and $23.3 \%$ and $45.0 \%$ higher than that of AB. Moreover, the differences in SOC, TN, POC and LOC of RP were 25.05-85.29\% higher than that of $\mathrm{CK}$, and 61.78-90.70\% higher than that of $\mathrm{AB}$ in soil depth of 100 $200 \mathrm{~cm}$.

$\mathrm{Gu}$ et al., (2017) revealed that SOC concentration in all treatments decreased with soil depth. The significant differences of SOC among treatments were solely at depths of 0 $40 \mathrm{~cm}$, where soil physicochemical properties changed. Further changes would have occurred following activity by microorganisms. Average SOC content at depths of $0-40 \mathrm{~cm}$ in ST and GT were $6.26 \mathrm{~g}$ $\mathrm{kg}^{-1}$ and $\quad 6.59 \quad \mathrm{~g} \quad \mathrm{~kg}^{-1}$ respectively, significantly higher than that of $5.44 \mathrm{~g} \mathrm{~kg}^{-1}$ in CK. The use of ST and GT increased SOC by $15.15 \%$ and $21.14 \%$, respectively. In the course of the growing season, SOC concentrations in all treatments presented substantial changes with seasons. Liu et al., (2019) reported that macro-aggregate proportion under cropland was significantly lower than under abandoned cropland and 
native vegetation land at the $0-20 \mathrm{~cm}$ depth. Micro-aggregate proportions under abandoned cropland and native vegetation land were significantly lower than under cropland in the soils at the $0-30 \mathrm{~cm}$ depth. Silt + clay-sized fraction proportion under cropland was larger than under abandoned cropland and native vegetation land in the soils at the $0-10 \mathrm{~cm}$ depth. Macro-aggregates accounted for $63-83 \%$ of all sized aggregates. Furthermore, macro-aggregates were generally more sensitive to land management than smaller sized aggregates.

Patra et al., (2018) reported that the soil bulk densities $(\rho b)$ increased significantly with increase in soil depth under all treatments. However, no statistically significant differences were observed for depths beyond $15 \mathrm{~cm}$ under all treatments. The $\rho b$ ranged from $1.43(0-5 \mathrm{~cm}$ depth) to $1.70(15-20 \mathrm{~cm}$ depth) $\mathrm{Mg} \mathrm{m}^{-3}$ under NTMWMB, $1.46(0-5$ $\mathrm{cm}$ depth) to $1.68(10-15 \mathrm{~cm}$ and $15-20 \mathrm{~cm}$ depths) $\mathrm{Mg} \mathrm{m}^{-3}$ under NT-RWMB, 1.42 (0-5 $\mathrm{cm}$ depth) to $1.70(15-20 \mathrm{~cm}$ depth $) \mathrm{Mg} \mathrm{m}^{-3}$ under RT-RWMB and 1.45 (0-5 cm depth) to $1.69(10-15 \mathrm{~cm}$ and $15-20 \mathrm{~cm}$ depths $) \mathrm{Mg}$ $\mathrm{m}^{-3}$ under CT-RW. Among the treatments, lowest $\rho b\left(1.42 \mathrm{Mg} \mathrm{m}^{-3}\right)$ was observed in the topsoil layer $(0-5 \mathrm{~cm})$ under RT-RWMB followed by NT-MWMB (1.43 $\left.\mathrm{Mgm}^{-3}\right)$, CTRW (1.45 $\mathrm{Mg} \mathrm{m}^{-3}$ ) and NT-RWMB (1.46 Mg $\mathrm{m}^{-3}$ ) [Fig.3a]. Therefore, the depth distributions of concentrations of SOC are shown in (Figure 3b). Values decreased with increase in soil depth under all treatments and depth distribution of SOC also differed among the different treatments. Values ranged from 10.65 (0-5 cm depth) to $3.04(25-30 \mathrm{~cm}$ depth) $\mathrm{g} \mathrm{kg}^{-1}$ under NT-MWMB, 10.27 (0-5 $\mathrm{cm}$ depth) to3.30 (25-30 cm depth) $\mathrm{g} \mathrm{kg}^{-1}$ under NT-RWMB, 7.86 (0-5 cm depth) to $2.36 \mathrm{~g} \mathrm{~kg}^{-1}(25-30 \mathrm{~cm}$ depth) under RTRWMB and $5.90(0-5 \mathrm{~cm}$ depth) to $2.64 \mathrm{~g}$ $\mathrm{kg}^{-1}$ (20-25 cm depth) under CT-RW. The highest concentrations of SOC were observed under NT-MWMB at 0-5 cm depth, whereas at 5-10, 10-15 and 15-20 cm soil depths, the highest SOC concentrations were observed under RT-RWMB. At 20-25 and 25-30 cm soil depths NT-RWMB contained the highest concentrations of SOC. The topsoil $(0-5 \mathrm{~cm}$ depth) SOC concentrations differed significantly from the lower layers under NTMWMB and NT-RWMB, whereas, the same was not detected under RT-RWMB and CTRW. The concentrations of SOC did not differ significantly from each other in the lower soil layers (>10 cm depth) under NT-MWMB and NT-RWMB. However, under RTRWMB and CT-RW, values did not differ significantly in the lower layers only beyond $20 \mathrm{~cm}$ of soil depth. The concentrations of SOC at $0-5 \mathrm{~cm}$ depth under NT-MWMB and NT-RWMB were not significantly different from each other. At the same depth, SOC values also did not differ significantly under RT-RWMB and CT-RW. However, the topsoil $(0-5 \mathrm{~cm}) \mathrm{SOC}$ concentrations differed significantly between the no-till treatments (NT-MWMB and NTRWMB) and the treatments having tillage operations (RT-RWMB and CT-RWMB). At 5-10 and 10-15 cm soil depths, the SOC concentrations under RT-RWMB varied significantly from other treatments.

Yu et al., (2020) reported that $-10 \mathrm{~cm}$ depth and the lowest value $\left(1.370 \mathrm{~g} \mathrm{~kg}^{-1}\right)$ in the SUA treatment at the $40-50 \mathrm{~cm}$ depth. The range of the SOC concentrations across the soil profile was 10.970, 7.230, 6.937, 4.408, and $6.025 \mathrm{~g} \mathrm{~kg}^{-1}$ for the LEY, PUC, ECH, SUA, and CHL treatments, respectively. Vegetation type had significant effects on the SOC concentration. The SOC concentration at $0-10 \mathrm{~cm}$ depth was ranked in the order of $\mathrm{LEY}>\mathrm{ECH}>\mathrm{PUC}>\mathrm{CHL}>\mathrm{SUA}$. Compared with the SUA and CHL treatments, SOC concentrations in LEY and ECH treatments were significantly higher at the 10-20 cm depth. At 20-50 cm depth, significantly higher SOC concentrations were 
found in treatments with $\mathrm{LEY} \approx \mathrm{ECH}>\mathrm{PUC}$ $\approx$ CHL $>$ SUA (Fig. 9a). The average SOC concentration at $0-50 \mathrm{~cm}$ depth was 7.418 , $5.268,6.350,3.308$, and $4.876 \mathrm{~g} \mathrm{~kg}^{-1}$ for the LEY, PUC, ECH, SUA, and CHL treatments, respectively. The SOCS under LEY, PUC, ECH, SUA, and CHL was 34.180, 25.923,

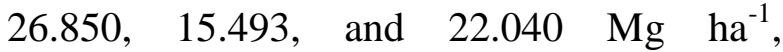
respectively, at the $0-20 \mathrm{~cm}$ depth and $22.256,15.438,22.313,10.919$, and 16.318 $\mathrm{Mg} \mathrm{ha}^{-1}$, respectively, at the $20-50 \mathrm{~cm}$ depth.

Total carbon stocks in the fractions and layers up to a 1-m depth

Devine et al., (2014) observed that $0-5 \mathrm{~cm}$, NT and FS aggregate size fractions were significantly elevated for SOC and fine fractions compared to $\mathrm{CT}$. In POC, increasing $\mathrm{C}$ from $\mathrm{CT}>\mathrm{NT}>\mathrm{FS}$ was evident in all aggregate sizes but significant at 0.05 for only the $>2000 \mu \mathrm{m}$. From $5-15 \mathrm{~cm}$, there were no significant differences between $\mathrm{CT}$ and NT for any of the size class and $\mathrm{C}$ fraction combinations, while the two largest aggregate size classes were significantly elevated in FS with respect to NT for SOC and all three classes were greater for POC. FS also exceeded CT but only in the small and micro aggregate fractions for POC. There were no significant differences for any of the size class and $\mathrm{C}$ fraction combinations from $15-28 \mathrm{~cm}$.

Mangalassery et al., (2014) revealed that zero tilled soils contained significantly more soil organic matter (SOM) than tilled soils. Soil from the $0-10 \mathrm{~cm}$ layer contained more SOM than soils from the 10-20 cm layers in both zero tilled (7.8 and $7.4 \%$ at $0-10 \mathrm{~cm}$ and 10 $20 \mathrm{~cm}$ respectively) and tilled soils (6.6\% at $0-10 \mathrm{~cm}$ and $6.2 \%$ at $10-20 \mathrm{~cm})$. Wang et al.(2018) reported that tillage system change influenced SOC content, NT, ST, and BT showed higher values of SOC content and increased 8.34, 7.83, and $1.64 \mathrm{MgCha}^{-1}$, respectively, compared with CT. Among the changed tillage systems, NT and ST showed a $12.5 \%$ and $11.6 \%$ increase in SOC content then BT, respectively. Tillage system change influenced SOC stratification ratio values, with higher value observed in BT and NT compared CT but ST. Therefore, in loess soil, changing tillage system can significantly improve SOC storage and change profile distribution.

Dhaliwal et al., (2018) revealed that the mean SOC concentration decreased with dry stable aggregates (DSA) and water stable aggregates (WSA). In DSA, the mean SOC concentration was 58.06 and $24.2 \%$ higher in large and small macro-aggregates than in microaggregates respectively; in WSA it was 295.6 and $226.08 \%$ higher in large and small macroaggregates than in micro-aggregates respectively in surface soil layer. The mean SOC concentration in surface soil was higher in DSA $(0.79 \%)$ and WSA $(0.63 \%)$ as compared to bulk soil $(0.52 \%)$. Zhao et al., (2014) observed that SOC distribution in soil aggregate fractions of different vegetation types was shown in Figure 4. Microaggregates $(<0.25 \mathrm{~mm}$ ) of five vegetation types had higher SOC content than macroaggregates. However, SOC contents in macroaggregates (>0.25 mm) of Rr, Po, Pt, and $\mathrm{Ab}$ were greater than that of Sc, suggesting that the distribution of SOC contents appeared to have shifted from the micro-aggregates (< $0.25 \mathrm{~mm}$ ) in low $\mathrm{C}$ input systems to the macro-aggregates in high $\mathrm{C}$ input systems. It was mainly due to micro-aggregate formation within macro-aggregates. Micro-aggregates occluded in the macro-aggregates can serve as an indicator for $\mathrm{C}$ sequestration.

Zhao et al., (2014) revealed that the SOC, TN, POC and LOC stocks of RP were significantly increased which were $0.43-5.8$ $\mathrm{Mgha}^{-1}, 0.25-4.70 \mathrm{Mgha}^{-1}, 0.44-9.14 \mathrm{Mgha}^{-1}$ and 1.49-11.38 $\mathrm{Mgha}^{-1}$ higher than that of SC in soil layers of $0-10,10-40,40-100$ and 
100-200 cm, respectively. Moreover, the stocks of SOC, TN, POC and LOC in soil layer of $100-200 \mathrm{~cm}$ of RP were higher than that of $\mathrm{CK}$ and $\mathrm{AB}$ by $15.4-32.1 \%$ and 21.8 $43.1 \%$, respectively (Fig. 5).

Zhao et al., (2015) also found that the concentrations of SOC decreased with increasing soil depth, and the depth distribution of SOC differed among treatments in both the wheat and maize seasons. At the wheat harvest, the SOC concentrations were the highest under NT at the $0-5$ and $5-10 \mathrm{~cm}$ depths, but the highest under PT at the 10-20, 20-30, and 30-50 cm depths. Furthermore, the SOC concentrations under RT fell between those for PT and NT at all soil depths except $5-10 \mathrm{~cm}$. At the maize harvest, a similar trend as for the wheat harvest was observed among the treatments. Comparing to the maize harvest, the SOC concentrations under NT increased by $12.17 \%, 17.13 \%$, and $5.56 \%$ at the $0-5,5-10$ and 10-20 cm depths, respectively, but decreased by $6.97 \%$ at the $20-30 \mathrm{~cm}$ depth at the wheat harvest. Similar trends were also observed under RT and PT, for which SOC increased at the $0-5,5-10$ and $10-20 \mathrm{~cm}$ depths and decreased or remained constant for the $20-30$ and $30-50 \mathrm{~cm}$ depths.

Naresh et al.(2018) reported that conservation tillage practices significantly influenced the total soil carbon (TC), Total inorganic carbon (TIC), total soil organic carbon (SOC) and oxidizable organic carbon (OC) content of the surface $(0-15 \mathrm{~cm})$ soil. Wide raised beds transplanted rice and zero till wheat with $100 \%\left(\mathrm{~T}_{9}\right)$ or with $50 \%$ residue management $\left(\mathrm{T}_{8}\right)$ showed significantly higher TC, SOC content of 11.93 and $10.73 \mathrm{~g} \mathrm{~kg}^{-1}$,respectively in $\mathrm{T}_{9}$ and 10.98 and $9.38 \mathrm{~g} \mathrm{~kg}^{-1}$, respectively in $\mathrm{T}_{8}$ as compared to the other treatments. Irrespective of residue incorporation/ retention, wide raised beds with zero till wheat enhanced $53.6 \%, 33.3 \%, 38.7 \%$ and
$41.9 \%$ of TC, TIC, SOC and OC, respectively, in surface soil as compared to conventional tillage with transplanted rice cultivation. Simultaneously, residue retention caused an increment of $6.4 \%, 7.4 \%, 8.7 \%$ and $10.6 \%$ in TC, TIC, SOC and OC, respectively over the treatments without residue management. Concerning the organic carbon storage, SOCs varied between $31.9 \mathrm{Mg} \cdot \mathrm{ha}^{-1}$ and $25.8 \mathrm{Mgha}^{-1}$ under NT, while, in tilled treatments, SOCs ranged between 28.8 $\mathrm{Mgha}^{-1}$ and $24.8 \mathrm{Mgha}^{-1}$.

Wang et al., (2019) reported that the silt +clay fraction accounted for 9\%-13\% and the large macro-aggregates accounted for $0 \%-10 \%$. In the $0-10$ and $10-20 \mathrm{~cm}$ layers, the NT treatment produced the highest proportion of large and small macro-aggregates, with mean values of $6 \%$ and $33 \%$, respectively, whereas the proportion of large and small macroaggregates under CT was $0 \%$ and $21 \%$, respectively (Fig. 6a). The positive effects of the RT and NT treatments were mainly concentrated on the small macro-aggregates. Compared with CT, the mass proportions of small macro-aggregates were higher in the $10-100 \mathrm{~cm}$ layer, accounting for $11 \%-36 \%$ under RT and $7 \%-40 \%$ in all layers under NT. Except for some individual values, CT soil had the highest proportion of the microaggregate and silt +clay fractions. Moreover, the different aggregates, the highest OC contents were found in the small macroaggregates in the 0-60 $\mathrm{cm}$ layer, with a range of 37-88 $\mathrm{g} \mathrm{Ckg}^{-1}$ aggregate, which was significantly higher than that of the large macro-aggregates, micro-aggregates, and the silt +clay fraction (Fig. 6b). Compared with CT, the NT treatment significantly increased the OC contents in the upper 10-cm layer in the large macro-aggregates, micro-aggregates, and the silt +clay fraction by $31 \%, 30 \%$, and $36 \%$, respectively (Fig. 6b). In the $10-100 \mathrm{~cm}$ layer, OC contents under NT decreased compared with those under CT, except for the 
silt +clay fraction in the $40-60 \mathrm{~cm}$ layer. The RT treatment increased OC contents in the small macro-aggregates mainly from the $0-10$ $\mathrm{cm}$ to the $60-80 \mathrm{~cm}$ layers, with a $1 \%-58 \%$ improvement compared to $\mathrm{CT}$. In the large macro-aggregates, RT significantly increased OC contents in the $0-10$ and $40-60 \mathrm{~cm}$ soil layers by $58 \%$ and $51 \%$, respectively. In the silt +clay fraction, RT significantly increased OC contents in the 10-20, 20-40, and 40-60 $\mathrm{cm}$ layers by $31 \%, 34 \%$, and $52 \%$, respectively. The differences in OC contents in micro-aggregates between the RT and CT treatments were only significant in the 40-60 cm layer.

\section{Storage of SOC}

Zhao et al., (2015) reported that the SOC storage under NT was significantly higher than that under PT in the surface soil (top10 $\mathrm{cm})$ by $10.82 \%$ and $8.16 \%$ at the $0-5$ and 0 $10 \mathrm{~cm}$ depths, respectively. However, no statistically significant differences were observed among the three treatments in the 0 $50 \mathrm{~cm}$ soil profile in the maize season, and the SOC storage in this soil layer was $3.82 \%$ and $6.28 \%$ higher than that under NT and RT, respectively. Additionally, the SOC storage was greater under RT than that under PT in the $0-5 \mathrm{~cm}$ layer by $6.53 \%$, but no statistically significant differences existed between the two treatments in the $0-10,0-20$, 0-30, and $0-50 \mathrm{~cm}$ layers. In the wheat season, the SOC storage was still higher under NT than that under PT in the $0-5 \mathrm{~cm}$ and $0-10 \mathrm{~cm}$ layers by $7.19 \%$ and $4.26 \%$, respectively. Furthermore, the SOC storage increased more under PT when the soil depth increased from the 0-5to0-50 depth than that under NT or RT. For the $0-50$ depth, the SOC storage was significantly greater under PT by $5.54 \%$ than that under NT and by $6.98 \%$ than that under RT. Moreover, the SOC storage was significantly higher under NT than that under RT at $0-5$ and $0-10 \mathrm{~cm}$; however, no significant differences existed at the 0-20, 30, and 50 depths.

Patra et al., (2018) observed that the SOC storage at $0-10 \mathrm{~cm}$ soil depth was the highest under NT-MWMB (12.49 $\left.\mathrm{Mg} \mathrm{ha}^{-1}\right)$ followed by NT-RWMB (12.12 $\mathrm{Mg} \mathrm{ha}^{-1}$ ), RT-RWMB (11.52 $\mathrm{Mg} \mathrm{ha}^{-1}$ ) and CT-RW (8.57 Mg ha ${ }^{-1}$ ). No statistically significant difference existed among NT-MWMB, NT-RWMB and RTRWMB treatments. However, storage of SOC at $0-10 \mathrm{~cm}$ depth was significantly lower under CT-RW compared to other treatments. The storage of SOC at 0-25 cm depth was the highest under RT-RWMB followed by NTRWMB, NTMWMB and CT-RW. However, it was only significantly higher than under CT-RW. At 0-30 cm soil depth, NT-RWMB stored the highest amount of SOC $(25.32 \mathrm{Mg}$ $\mathrm{ha}^{-1}$ ) and it differed significantly only from that under CT-RW (20.83 $\mathrm{Mg}$ ha $\left.{ }^{-1}\right)$. However, there were no statistically significant differences among NT-MWMB, NT-RWMB and RT-RWMB and NTMWMB, RT-RWMB and CTRW. The TN storage at $0-5 \mathrm{~cm}$ depth followed the order of NT-MWMB > NT-RWMB > RT-RWMB > CTRW. However, the trend was different with an increase in soil depth. At $0-15 \mathrm{~cm}, 0$ $20 \mathrm{~cm}, 0-25 \mathrm{~cm}$ and $0-30 \mathrm{~cm}$ soil depths, the storage of TN was the highest under RTRWMB followed by NT-MWMB, NTRWMB and CT-RW. At these soil depths, the TN storage under RT-RWMB differed significantly only from that under CT-RW. For the storage of TN at $0-30 \mathrm{~cm}$, there was no significant difference among the different treatments.

Wang et al., (2019) also found that the SOC contents in all treatments displayed a decreasing trend from topsoil $(0-10 \mathrm{~cm})$ to deep soil $(80-100 \mathrm{~cm})$. RT resulted in the highest SOC content in all layers except the 80-100 cm layer. Compared with the CT treatment, RT significantly increased SOC 
contents in the $0-10,10-20,20-40,40-60$, and $60-80 \mathrm{~cm}$ layers, with values of $59 \%$, $28 \%, 29 \%, 77 \%$, and $24 \%$, respectively. NT significantly increased SOC contents in the 0 $10,10-20,20-40$, and 40-60 cm layers, with values of $20 \%, 19 \%, 3 \%$, and $23 \%$, respectively. There was no significant difference in the SOC content between RT and CT in the 80-100 cm layer. In the deep soil of the $60-80$ and $80-100 \mathrm{~cm}$ layers, the SOC content in NT soil was significantly lower than that in CT soil. Yu et al., (2020) also found that the greater SOCS was observed in the LEY treatment as compared to $\mathrm{PUC} \approx \mathrm{ECH}>\mathrm{CHL}>\mathrm{SUA}$ treatments at 0-10 cm depth. At the 10-20 cm depth, SOCS in the LEY, PUC and ECH treatments was significantly higher than that in the SUA and CHL treatments. Similar to the SOC concentration, SOCS at 20 to $50 \mathrm{~cm}$ depth was ranked as $\mathrm{LEY} \approx \mathrm{ECH}>\mathrm{PUC} \approx \mathrm{CHL}>$ SUA (Table 1). The SOCS under LEY, PUC, ECH, SUA, and CHL was 34.180, 25.923, 26.850, 15.493, and $22.040 \mathrm{Mg} \mathrm{ha}{ }^{-1}$, respectively, at the $0-20 \mathrm{~cm}$ depth and 22.256, 15.438, 22.313, 10.919, and 16.318 $\mathrm{Mg} \mathrm{ha}^{-1}$, respectively, at the $20-50 \mathrm{~cm}$ depth.

Table.1 Storage of SOC under different vegetation types

\begin{tabular}{|c|c|c|c|c|c|}
\hline \multirow{2}{*}{$\begin{array}{c}\text { Soil Depth } \\
(\mathbf{c m})\end{array}$} & \multicolumn{5}{|c|}{ Storage of Soil Organic Carbon $\left(\mathbf{M g ~ h a}^{-1}\right)$} \\
\cline { 2 - 6 } & $\mathbf{L E Y}$ & $\mathbf{P U C}$ & $\mathbf{E C H}$ & SUA & CHL \\
\hline $\mathbf{0 - 1 0}$ & $20.625( \pm 0.465) \mathrm{Aa}$ & $14.453( \pm 0.632) \mathrm{Ba}$ & $15.275( \pm 0.181) \mathrm{Ba}$ & $9.035( \pm 0.209) \mathrm{Da}$ & $13.225( \pm 0.109) \mathrm{Ca}$ \\
\hline $\mathbf{1 0 - 2 0}$ & $13.555( \pm 0.739) \mathrm{Ab}$ & $11.470( \pm 1.599) \mathrm{Ab}$ & $11.575( \pm 0.464) \mathrm{Ab}$ & $6.458( \pm 0.653) \mathrm{Bb}$ & $8.815( \pm 0.240) \mathrm{Bb}$ \\
\hline $\mathbf{2 0 - 3 0}$ & $9.838( \pm 0.400) \mathrm{Ac}$ & $6.785( \pm 0.495) \mathrm{Bc}$ & $9.390( \pm 0.380) \mathrm{Ac}$ & $5.058( \pm 0.380) \mathrm{Cc}$ & $6.525( \pm 0.455) \mathrm{Bc}$ \\
\hline $\mathbf{3 0 - 4 0}$ & $7.208( \pm 0.197) \mathrm{Ad}$ & $4.973( \pm 0.099) \mathrm{Bcd}$ & $7.453( \pm 0.361) \mathrm{Ad}$ & $3.578( \pm 0.241) \mathrm{Cd}$ & $5.460( \pm 0.202) \mathrm{Bd}$ \\
\hline $\mathbf{4 0 - 5 0}$ & $5.210( \pm 0.304) \mathrm{ABe}$ & $3.680( \pm 0.298) \mathrm{Bd}$ & $5.470( \pm 0.399) \mathrm{Ae}$ & $2.283( \pm 0.151) \mathrm{Ce}$ & $4.333( \pm 0.299) \mathrm{Be}$ \\
\hline $\mathbf{0 - 5 0}$ & $56.436( \pm 1.038) \mathrm{A}$ & $41.361( \pm 1.928) \mathrm{C}$ & $49.163( \pm 0.804) \mathrm{B}$ & $26.412( \pm 0.858) \mathrm{D}$ & $38.358( \pm 0.738) \mathrm{C}$ \\
\hline
\end{tabular}

Leymus chinensis (LEY), Puccinellia tenuiflora (PUC), Echinochloa phyllopogon (ECH), saline seepweed (SUA), and Chloris virgata Swartz (CHL)

Fig.1a Effects of straw return to deep soil on the easily oxidized organic carbon (EOC) contents at three soil depths

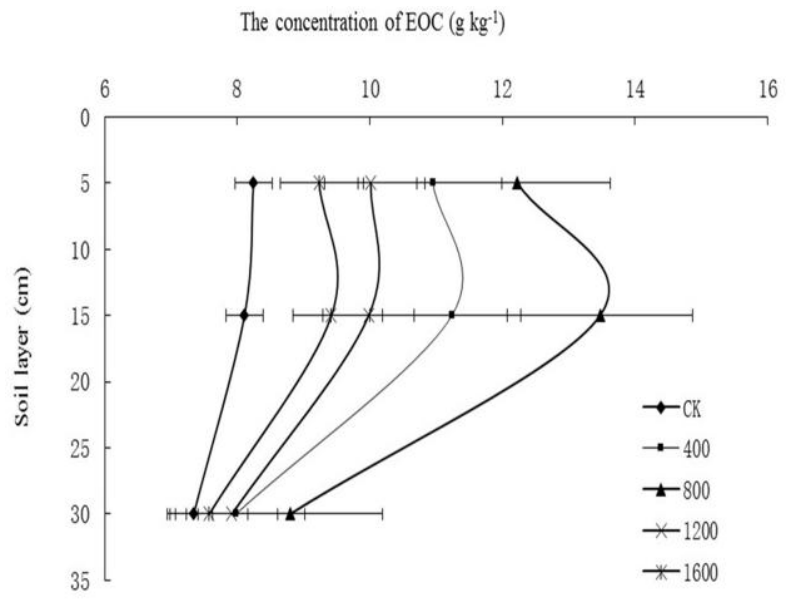


Fig.1b Effects of returning straw to deep soil on the soil light fraction organic carbon (LFOC) at three soil depths

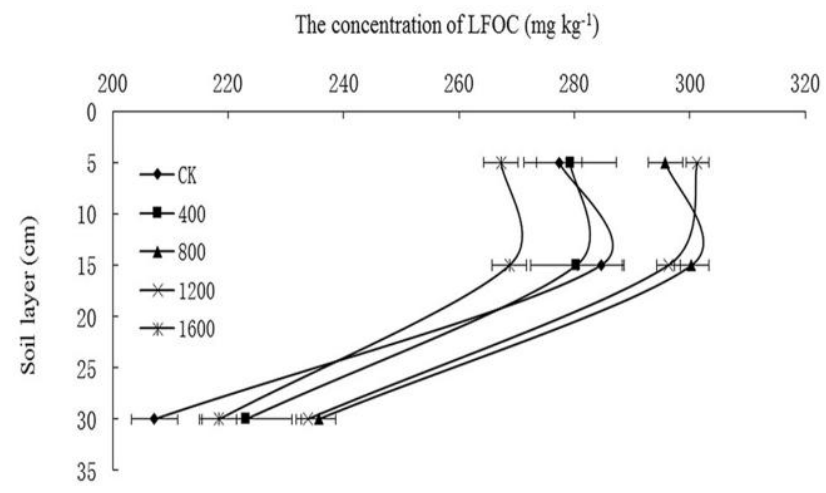

Fig.2a Distribution of soil organic carbon (SOC, A), total nitrogen (TN, B), particulate organic carbon (POC, C), and labile organic carbon (LOC, D) contents of different land used types in soil depth of $0-200 \mathrm{~cm}$
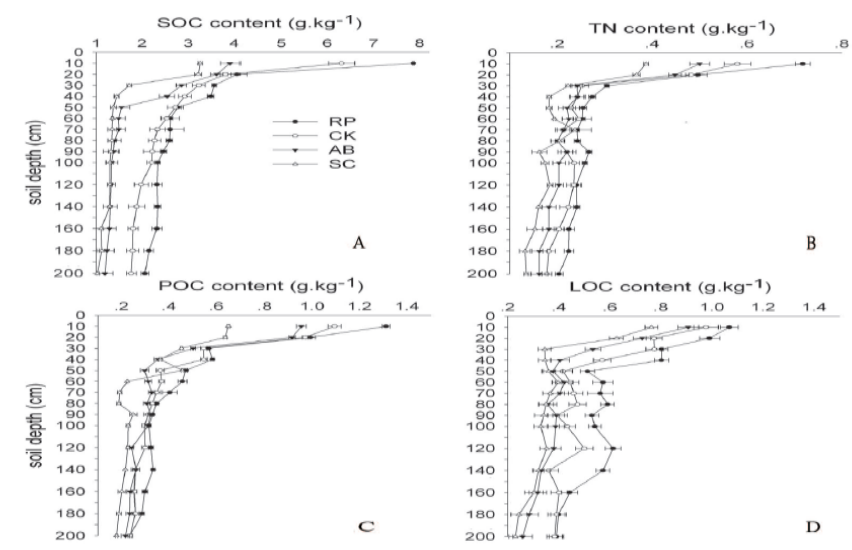

Fig.2b Differences in soil organic carbon (SOC, A), total nitrogen (TN, B), particulate organic carbon (POC, C), labile organic carbon (LOC, D) contents between SC and RP, CK or AB

$(\mathrm{RP} / \mathrm{CK} / \mathrm{AB}-\mathrm{SC})$
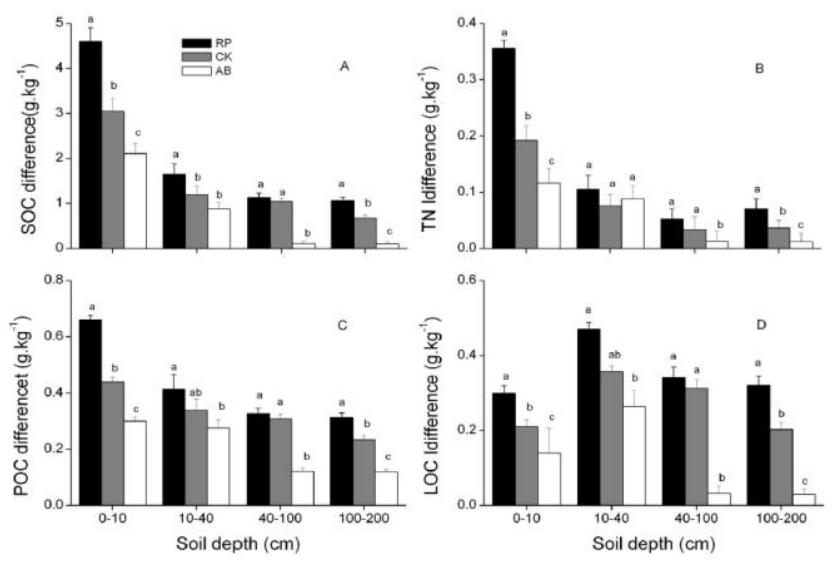
Fig.3a Depth distribution of soil bulk density $(\rho b)$ under different treatments Fig.3b Depth distribution of the concentrations of soil organic carbon (SOC) under different treatments

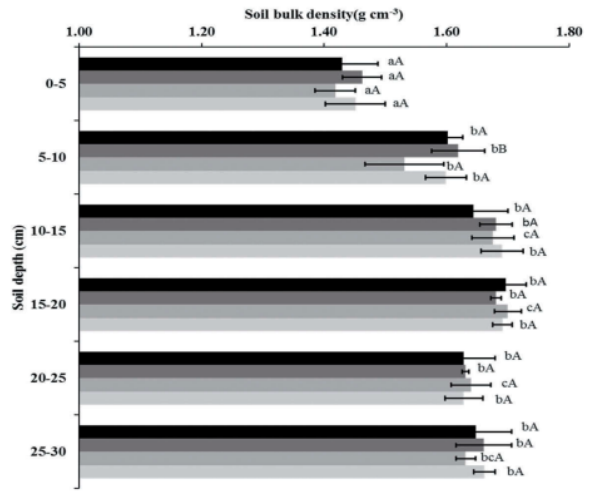

(a)
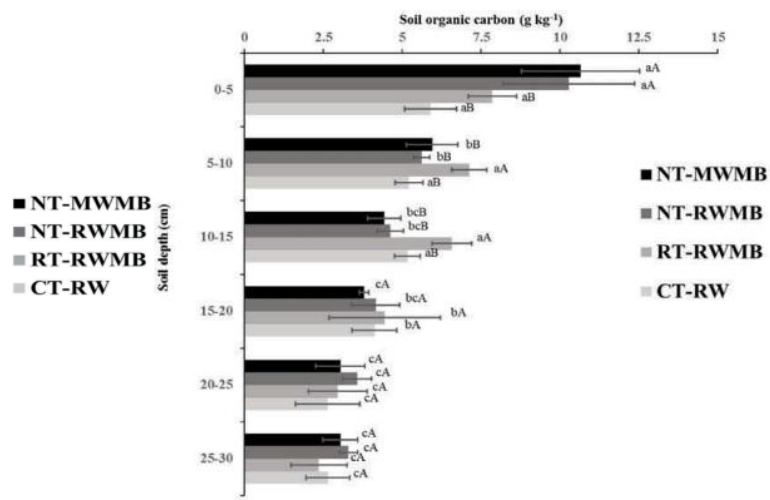

(b)

Fig.4 Distribution of soil organic carbon of different vegetation types

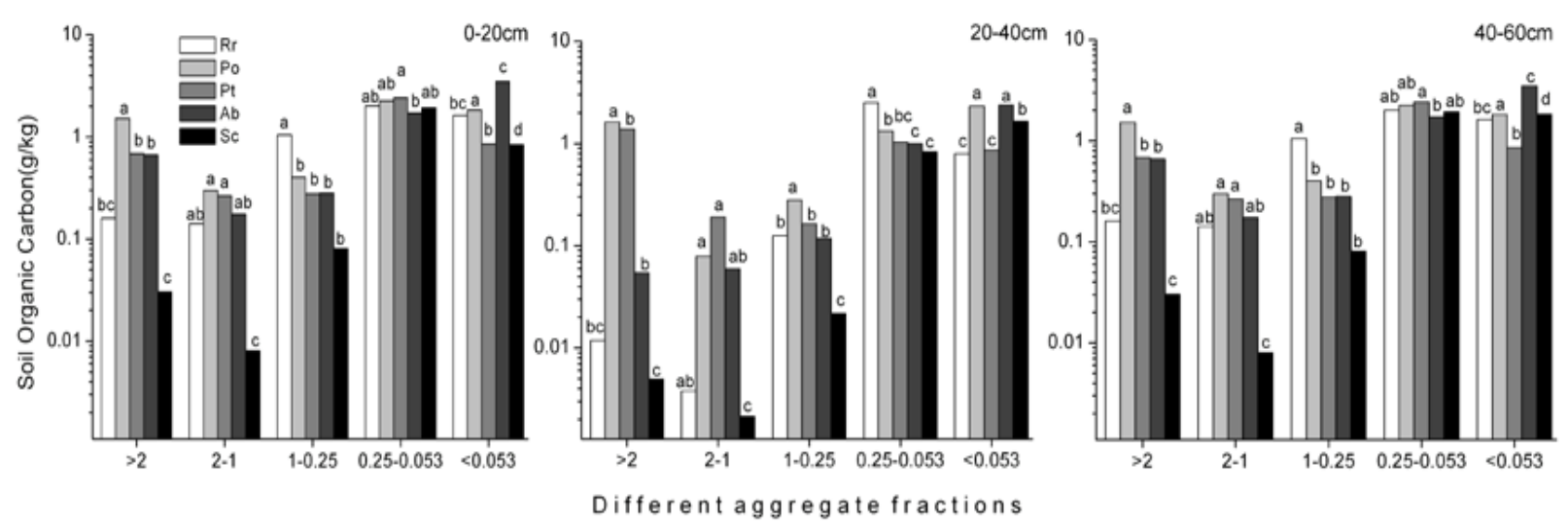

Fig.5 Stocks of soil organic carbon (SOC, A), total nitrogen (TN, B), particulate organic carbon (POC, C), labile organic carbon (LOC, D) of different land use types
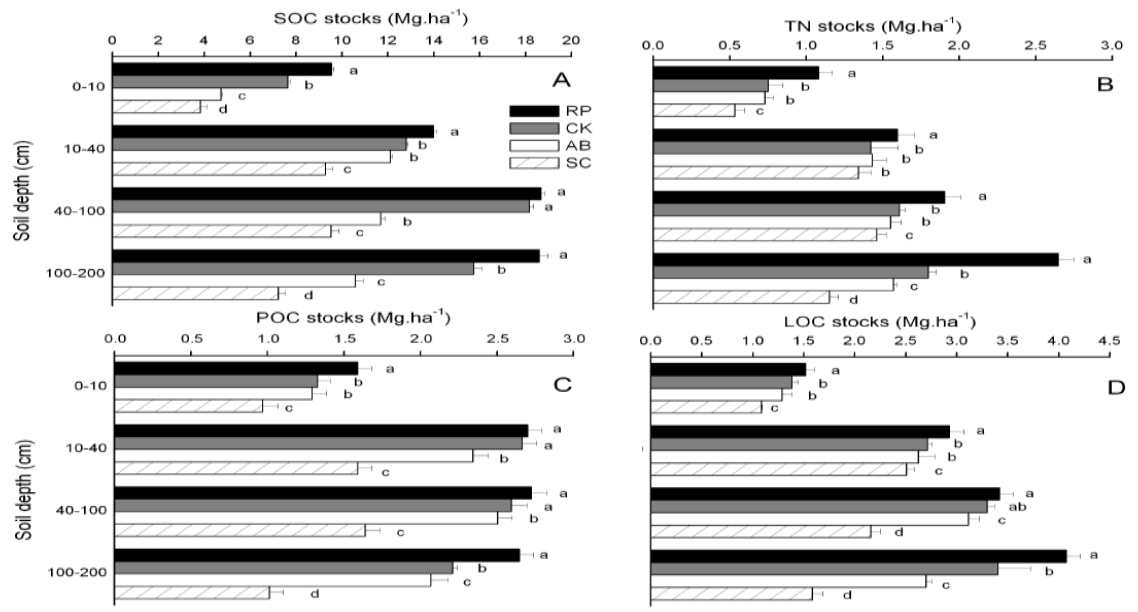
Fig.6a Soil organic carbon (SOC) content under conventional tillage with residue removal (CT), reduced tillage with residue incorporated (RT), and no-tillage with residue mulch (NT)

Fig.6b Aggregate-associated organic carbon (OC) content under CT, RT and NT

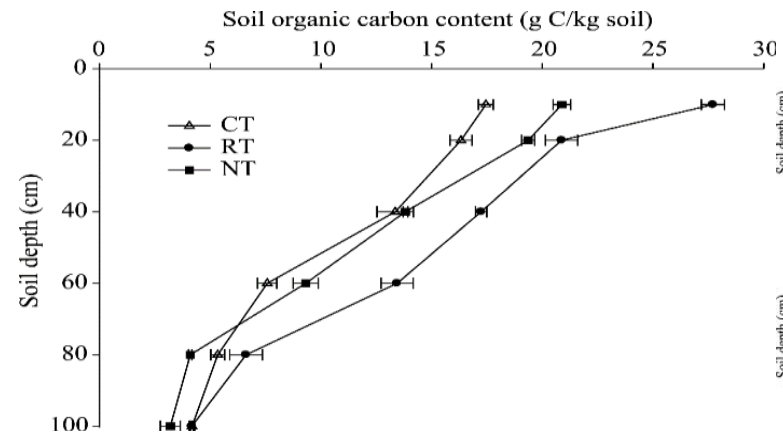

(a)

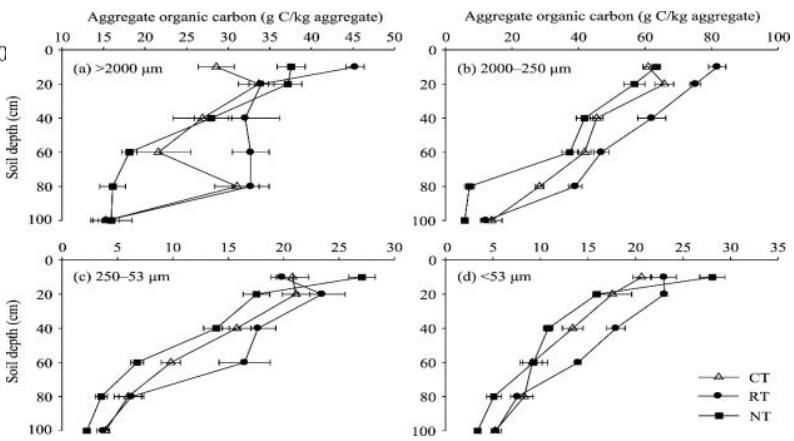

(b)

Fig.7a Organic carbon content of aggregates in soil under CT, RT and NT
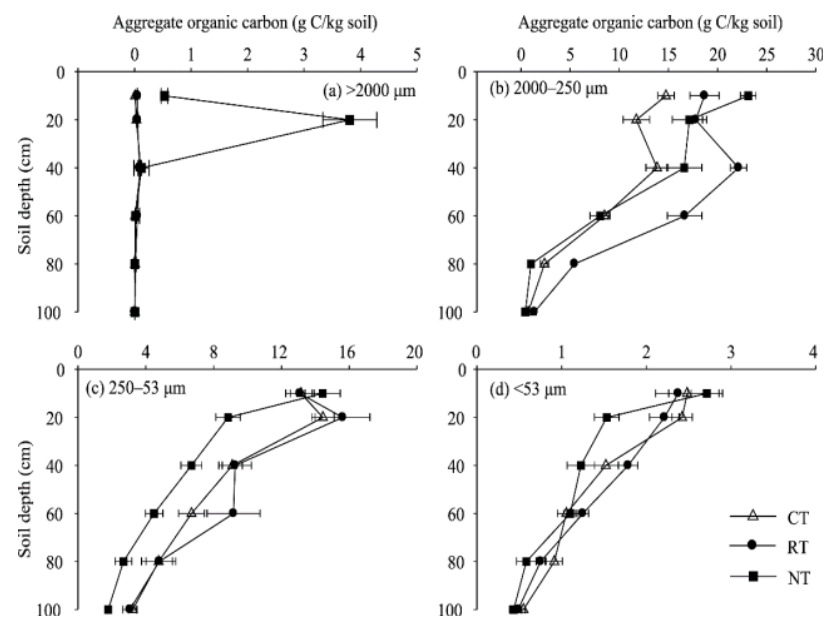

Fig.7b Aggregate sub-fraction distribution and associated organic carbon (OC) contents in small macro-aggregates under CT, RT and NT

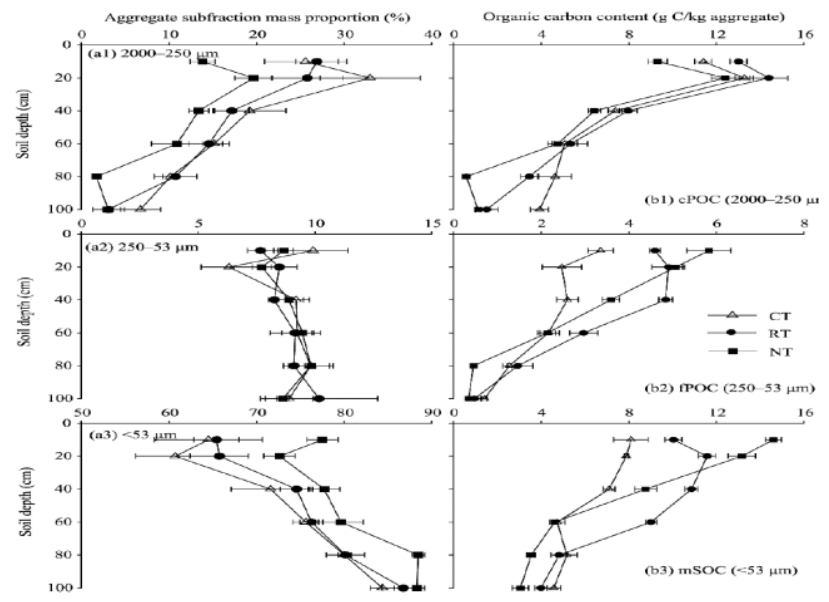


Fig.8 Comparison of stratification ratio of soil organic carbon (SOC, A), total nitrogen (TN, B), particulate organic carbon (POC, C), labile organic carbon (LOC, D) under different land use

types
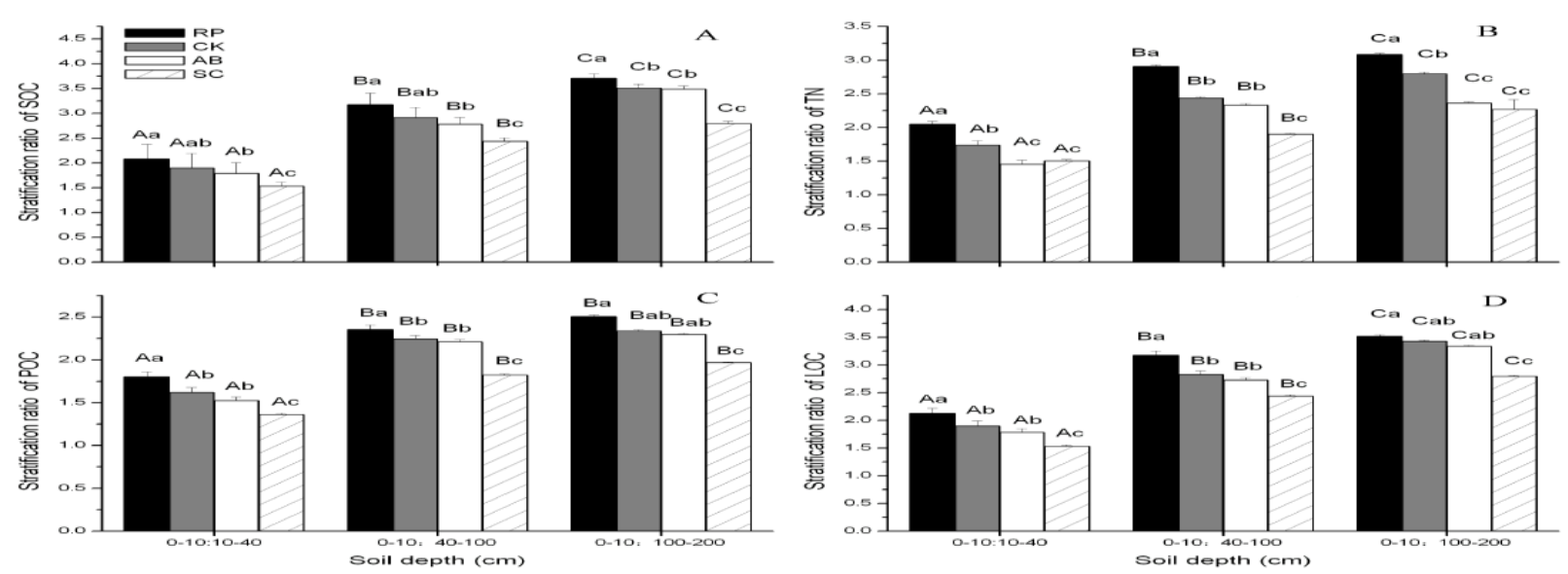

Fig.9a Depth distribution of SOC concentration under different vegetation types Fig.9b The stratification ratio of SOC concentration under different vegetation types

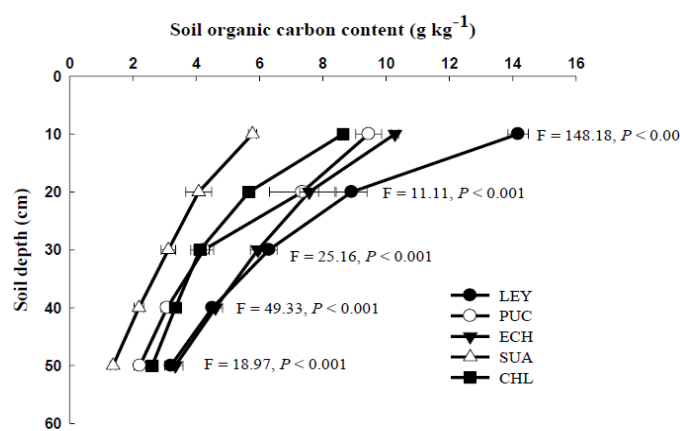

(a)

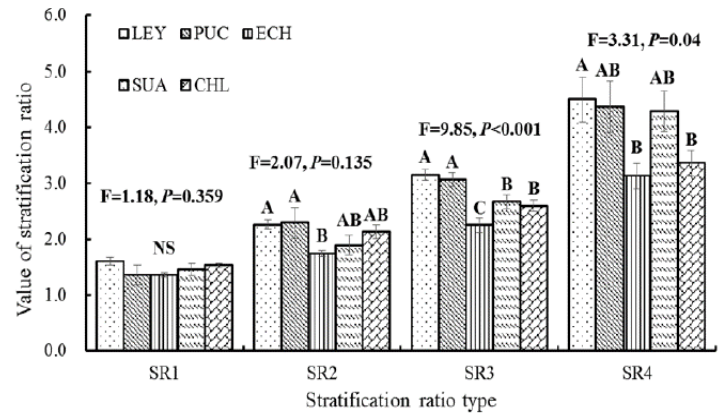

(b)

Fig.10a Enhanced Soil Carbon Storage under Agro-forestry and Afforestation Fig.10b SOC storage and the effects of climate, soil, and human activity variables

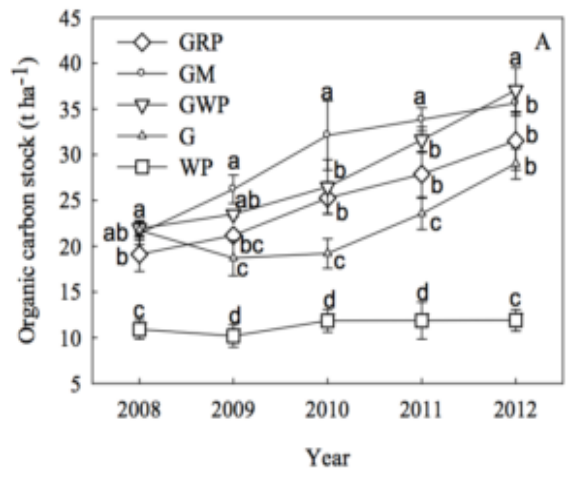

(a)

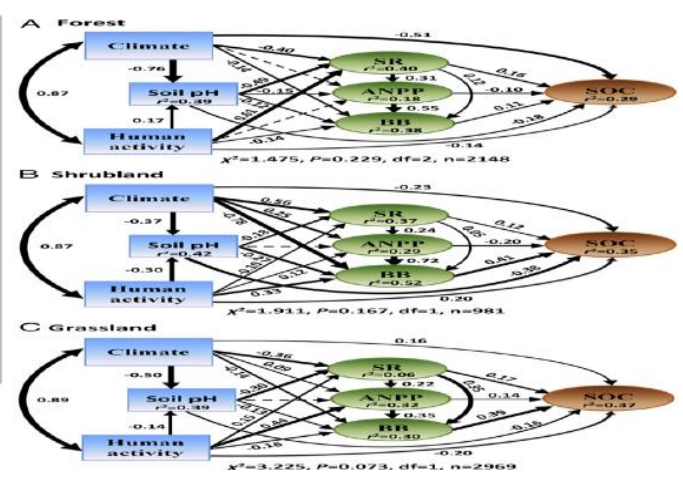

(b) 
Fig.11a Spatial distribution of average annual SOC change under different climatic scenarios

Fig.11b Annual SOC change from 2001 to 2019 under different management practices

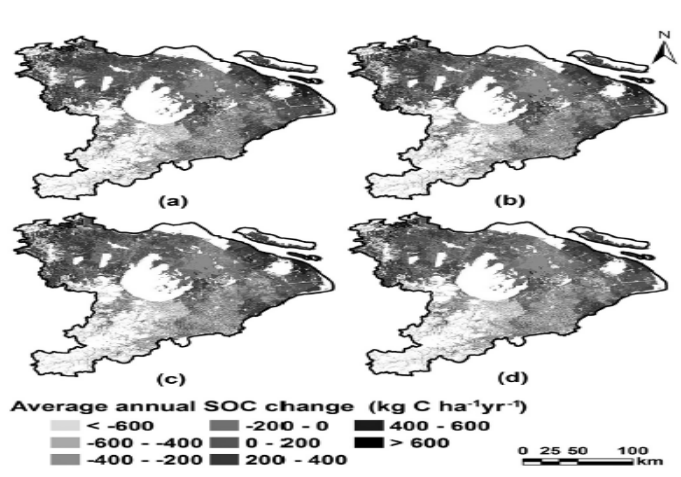

(a)

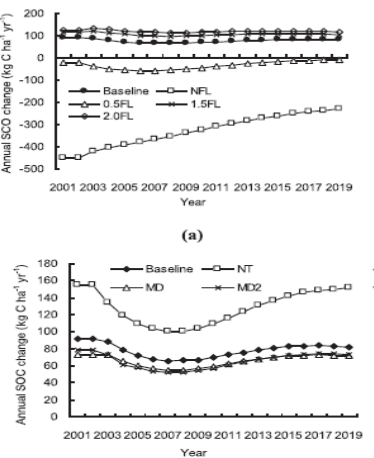

(c)

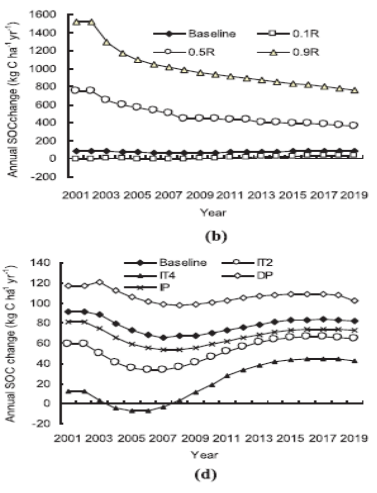

(b)
Zhou et al., (2020) concluded that the SOC concentration in the $\mathrm{WSA}_{2-5 \mathrm{~mm}}, \mathrm{WSA}_{0.5-1 \mathrm{~mm}}$, $\mathrm{WSA}_{0.25-0.5} \mathrm{~mm}, \quad \mathrm{WSA}_{0.106-0.25} \mathrm{~mm}$, and WSA $<0.106 \mathrm{~mm}$ were all significantly increased by $15.2 \%, 26.2 \%, 20.7 \%, 41.6 \%$, and $28.7 \%$ from SC treatment; by $11 \%, 35.6 \%, 24.5 \%$, $34.2 \%$, and $33.8 \%$ from CS treatment; and by $20.2 \%, 25.8 \%, 29.7 \%, 43.5 \%$, and $27.4 \%$ from FS treatment in comparison with the CC treatment, respectively. Simultaneously, compared with CC treatment, CS and FS treatments both significantly increased SOC concentration in the $\mathrm{WSA}_{>5} \mathrm{~mm}$ by $22.4 \%$ and $19.4 \%$, as well as SC and CS treatments both significantly increased SOC concentration in the $\mathrm{WSA}_{1-2} \mathrm{~mm}$ by $21.4 \%$ and $14.1 \%$, respectively. In addition, the $\mathrm{CS}$ and FS treatments both significantly increased SOC concentration by $17.6 \%$ and $14.1 \%$ compared with the $\mathrm{CC}$ treatment in bulk soils. Across all treatments, the SOC stock in the seven aggregates' sizes showed a similar tendency in the SOC concentration, although the bulk density differed a little among the treatments. Bulk density for the five treatments was in the range of $1.12-1.18 \mathrm{~g} \mathrm{~cm}^{-3}$. CS treatment had the highest SOC stock in the $\mathrm{WSA}_{>5} \mathrm{~mm}$, $\mathrm{WSA}_{0.5-1 \mathrm{~mm}}$, and $\mathrm{WSA}_{<0.106 \mathrm{~mm}}$ with $8.89 \mathrm{t}$ $\mathrm{hm}^{-2}, 8.59 \mathrm{t} \mathrm{hm}^{-2}$, and $3.75 \mathrm{t} \mathrm{hm}^{-2}$, respectively. While the FS treatment had the highest SOC stock in the $\mathrm{WSA}_{2-5 \mathrm{~mm}}(7.64 \mathrm{t}$ $\left.\mathrm{hm}^{-2}\right), \quad \mathrm{WSA}_{0.25-0.5} \mathrm{~mm}\left(7.10 \quad \mathrm{t} \quad \mathrm{hm}^{-2}\right)$, respectively. Furthermore, the SC treatment demonstrated the biggest SOC stock in the $\mathrm{WSA}_{1-2 \mathrm{~mm}}\left(8.80 \mathrm{t} \mathrm{hm}^{-2}\right)$ and $\mathrm{WSA}_{0.106-0.25}$ $\mathrm{mm}\left(6.64 \mathrm{t} \mathrm{hm}^{-2}\right)$, respectively. Except for $\mathrm{WSA}_{0.106-0.25 \mathrm{~mm}}$ and $\mathrm{WSA}_{<0.106 \mathrm{~mm}}$, the $\mathrm{FC}$ treatment documented the lowest SOC stock in all five other aggregate sizes. Furthermore, the SOC stock in the $\mathrm{WSA}_{2-5 \mathrm{~mm}}, \mathrm{WSA}_{1-2 \mathrm{~mm}}$, $\mathrm{WSA}_{0.5-1 \mathrm{~mm}}, \mathrm{WSA}_{0.25-0.5 \mathrm{~mm}}$, WSA $0.106-0.25 \mathrm{~mm}$, and $\mathrm{WSA}_{<0.106 \mathrm{~mm}}$ from the $\mathrm{SC}$ treatment, the stock in the $\mathrm{WSA}_{>5 \mathrm{~mm}}, \mathrm{WSA}_{0.5-1 \mathrm{~mm}}, \mathrm{WSA}_{0.25}$ $0.5 \mathrm{~mm}, \mathrm{WSA}_{0.106-0.25 \mathrm{~mm}}$, and $\mathrm{WSA}_{<0.106 \mathrm{~mm}}$ from the CS treatment were all significantly $(P<0.05)$ increased by $8 \%, 19.6 \%, 29.5 \%$, $18.3 \%, 63.1 \%$, and $34.7 \%$; and by $16.7 \%$, $43.1 \%, 20.6 \%, 40.2 \%$, and $39.4 \%$ compared with $\mathrm{CC}$ treatment, respectively. Similarly, the SOC stock in the $\mathrm{WSA}_{0.106-0.25 \mathrm{~mm} \text { and }}$ $\mathrm{WSA}_{<0.106 \mathrm{~mm}}$ from the FC treatment, and the stock in the $\mathrm{WSA}_{>5 \mathrm{~mm}}, \mathrm{WSA}_{2-5 \mathrm{~mm}}, \mathrm{WSA}_{0.5-1}$ ${ }_{m m}, \mathrm{WSA}_{0.25-0.5} \mathrm{~mm}, \quad \mathrm{WSA}_{0.106-0.25} \mathrm{~mm}$, and WSA $<0.106 \mathrm{~mm}$ from the FS treatment were also significantly increased by $10.7 \%$, and $23.8 \%$; and by $12.3 \%, 13.8 \%, 24.7 \%, 32.4 \%, 62.3 \%$, and 27.9 in comparison with the $\mathrm{CC}$ treatment, respectively.

Wang et al., (2019) observed that the OC content in aggregates was transformed by adding $1 \mathrm{~g} \mathrm{Ckg}^{-1}$ aggregate throughout the 
bulk soil, a different result for the OC content in aggregates (unit of $\mathrm{g} \mathrm{Ckg}^{-1}$ soil) was observed (Fig. 7a). After this transformation, NT significantly increased the OC content in large macro-aggregates down to a soil depth of $20 \mathrm{~cm}$ soil and in small macro-aggregates down to a soil depth of $40 \mathrm{~cm}$ compared with $\mathrm{CT}$. There was a significant effect of RT on the OC content in small macro-aggregates, which was $27 \%-129 \%$ higher than that in CT soil from the $0-10$ to $80-100 \mathrm{~cm}$ layers. Differences in the OC content in microaggregates and the silt +clay fraction between the RT and CT treatments were not significant at any depth, except for the 40-60 $\mathrm{cm}$ layer. However, the CT treatment, the OC content in cPOC was significantly increased by RT only in the $0-10 \mathrm{~cm}$ layer (Fig. 7b). Compared with the CT treatment, RT significantly increased the OC content in $\mathrm{PPOC}$ and $\mathrm{mSOC}$ in the 0-60 cm layers, with improvements of $37 \%-99 \%$ and $24 \%-90 \%$, respectively. The NT treatment significantly increased the OC content in $\mathrm{PPOC}$ and $\mathrm{mSOC}$ in the $0-40 \mathrm{~cm}$ layers, with improvements of $38 \%-105 \%$ and $23 \%-80 \%$, respectively. However, the OC content in the sub-fractions under RT and NT was lower than that under CT in the 60-100 $\mathrm{cm}$ layers, except for PPOC under RT in the 60-80 cm layer.

\section{Stratification of SOC}

Ma et al., (2016) reported that the differences in SMBC were limited to the surface layers $(0-5$ and $5-10 \mathrm{~cm})$ in the PRB treatment. There was a significant reduction in SMBC content with depth in all treatments. SMBC in the PRB treatment increased by $19.8 \%$, $26.2 \%, 10.3 \%, 27.7 \%, 10 \%$ and $9 \%$ at $0-5,5-$ $10,10-20,20-40,40-60$ and $60-90 \mathrm{~cm}$ depths, respectively, when compared with the TT treatment. The mean SMBC of the PRB treatment was $14 \%$ higher than that in the TT treatment. Zhao et al., (2014) concluded that the responses of SR in different land use types to change of soil depth were different (Fig. 8). The SR values of SOC, TN and LOC differed significantly among different soil depths while the SR values of LOC differed only between 0-10:10-40 cm, 0- 10:40-100 cm and 0-10:100-200 cm. Among four land use types, the SR values of SOC, TN, POC and LOC of RP were the highest, but that of SC were the lowest in each soil depth. The SR values of SOC, TN, POC and LOC were in a decreasing order of $\mathrm{CK}>\mathrm{AB}>\mathrm{SC}$. The SR values differed significantly between $C K$ and $\mathrm{AB}$ with $\mathrm{SC}$ while there was no significant difference between $\mathrm{CK}$ and $\mathrm{AB}$. Additionally, the ratios of SR values of SOC, TN, POC and LOC in the surface layer $(0-10 \mathrm{~cm})$ to that in layer of 10-40 cm were >2.0. Wang et al., (2010) this is mainly due to the fact that SOC input into subsoil is largely affected by plant roots and root exudates, dissolved organic matter and bioturbation. In addition, most important factors leading to protection of SOC in subsoil include the spatial separation of SOM, microorganisms and extracellular enzyme activity related to the heterogeneity of $\mathrm{C}$ input.

Zhao et al., (2015) observed that the SR of SOC increased significantly with increased soil depth at wheat harvest, the SR of SOC ranged from 1.07 to $3.95,1.13$ to 3.41 , and 1.03 to 2.98 for NT, RT, and PT, respectively for $0-5: 5-10,0-5: 10-20,0-5: 20-30$, and $0-$ $5: 30-50 \mathrm{~cm}$. The SR of SOC for $0-5: 5-10 \mathrm{~cm}$ under RT was significantly higher than that under PT. Compared with the undisturbed soil (NT), RT increased the SR of SOC for 0-5:5$10 \mathrm{~cm}$ without statistical significance but significantly decreased the SR of SOC for the other layers (10-20, 20-30, and 30-50 $\mathrm{cm}$ ). Furthermore, the SRs of SOC for 0-5:5$10,0-5: 10-20,0-5: 20-30$, and $0-5: 30-50 \mathrm{~cm}$ layer followed the order of $\mathrm{NT}>\mathrm{RT}>\mathrm{PT}$, indicating that the SR of SOC decreased with increased tillage intensity. At the maize harvest, SR of SOC was significant higher 
under NT than that under PT for $0-5: 5-10,0-$ $5: 10-20,0-5: 20-30$, and $0-5: 30-50 \mathrm{~cm}$. The SR ranged from 1.12 to $3.56,1.10$ to 3.18 , and 1.01 to 2.51 for NT, RT, and PT, respectively across the depth ratios. When compared with the wheat harvest, the SR at the maize harvest changed little for the $0-5: 5-$ 10and 10-20 cm depths but decreased for the 0-5:20-30 and 0-5:30-50 cm depths. Yu et al., (2020) observed that SR of SOC ranged from 1.355 to $1.603,1.735$ to $2.288,2.245$ to 3.150, and 3.128 to 4.503 for $\mathrm{SR}_{1}, \mathrm{SR}_{2}, \mathrm{SR}_{3}$, and $\mathrm{SR}_{4}$, respectively, among the five vegetation types. Vegetation type had no significant effect on $\mathrm{SR}_{1}$ and $\mathrm{SR}_{2}$ due to the narrow range. However, the influences of vegetation types on $\mathrm{SR}_{3}$ and $\mathrm{SR}_{4}$ were significant (Fig. 9b). $\mathrm{SR}_{3}$ of SOC was ranked as $\mathrm{LEY} \approx \mathrm{PUC}>\mathrm{SUA} \approx \mathrm{CHL}>\mathrm{ECH}$.

Patra et al., (2018) concluded that the SR of SOC increased significantly with increased soil depth under all treatments. Values ranged from 1.80 to $3.50,1.84$ to $3.12,1.10$ to 3.33 and 1.13 to 2.23 for NT-MWMB, NTRWMB, RT-RWMB and CT-RW, respectively, for $0-5: 5-10,0-5: 10-15,0$ 5:15-20, 0-5:20-25 and 0-5:25-30 cm soil depths. The SRs of SOC for 0-5:10-15 and subsequent lower layers were significantly different than the top 0-5:5-10 SR under NTMWMB, whereas, the same was observed only beyond 0-5: 15-20 for NT-RWMB and 0-5:20-25 for RTRWMB and CT-RW, indicating that SRs of SOC varied in response to differential amount of crop residue incorporation and the increased tillage intensity. The treatment-based comparison revealed that the SRs at 0-5:5-10 and 0 5:10-15 were not significantly different from each other under NTMWMB and NT-RWMB and under RT-RWMB and CT-RW. However, the no-tillage treatments (NT-MWMB and NT-RWMB) differed significantly from the tilled treatments (RT-RWMB and CT-RW). There were no significant differences among the SRs for lower soil depth ratios (beyond 0$5: 10-15 \mathrm{~cm}$ ) under all treatments.

Tripathi et al., (2014) observed that the significant positive correlations were observed between TOC and organic $\mathrm{C}$ fractions (POC and SMBC), illustrating a close relationship between TOC and POC and TOC and SMBC and that SOC is a major determinant of POC and SMBC. The microbial biomass carbon includes living microbial bodies (bacteria, fungi, soil fauna and algae). Divya et al., (2014); it is more sensitive to soil disturbance than TOC. The proportion of SMBC to TOC is evaluation of carbon availability indexes for agriculture soil, which is usually $0.5-4.6 \%$. Nair et al., (2010 also found that there was a correlation between organic carbon concentrations tree density and that soil near trees tended to store more carbon than in soil. SOC levels up to 20 $\mathrm{cm}$ in depth and total soil carbon up to $80 \mathrm{~cm}$ was greater in all treatments with trees, and lowest in the crop-only system (Fig. 10a). Chen et al., (2018) reported that favorable climate conditions to increase both species richness and belowground biomass, which had a consistent positive effect on SOC storage. Ecosystem management that maintains high levels of plant diversity can enhance SOC storage and other ecosystem services that depend on plant diversity (Fig. 10b).

Malviya, (2014) also indicated that irrespective of soil depth the SMBC contents were significantly higher under RT over CT This was attributed to residue addition increases microbial biomass due to increase in carbon substrate under RT. Ma et al., (2016) reported that the differences in SMBC were limited to the surface layers $(0-5$ and 5-10 $\mathrm{cm}$ ) in the PRB treatment. There was a significant reduction in SMBC content with depth in all treatments. SMBC in the PRB treatment increased by $19.8 \%, 26.2 \%, 10.3 \%$, 
$27.7 \%, 10 \%$ and $9 \%$ at $0-5,5-10,10-20,20$ $40,40-60$ and 60-90 cm depths, respectively, when compared with the TT treatment. The mean SMBC of the PRB treatment was $14 \%$ higher than that in the TT treatment. McGonigle and Turner, (2017) concluded that the MBC in cropland increased from $210 \mu \mathrm{g}$ $\mathrm{g}^{-1}$ at $15 \mathrm{~g} \mathrm{~kg}^{-1}$ SOC to only $530 \mu \mathrm{g} \mathrm{g}^{-1}$ at $45 \mathrm{~g}$ $\mathrm{kg}^{-1}$ SOC. In contrast, MBC in grassland increased from $440 \mu \mathrm{g} \mathrm{g}^{-1}$ at $15 \mathrm{gkg}^{-1} \mathrm{SOC}$ to $1190 \mu \mathrm{g} \mathrm{g}^{-1}$ at $45 \mathrm{gkg}^{-1}$, thereafter increasing further to $1800 \mu \mathrm{g} \mathrm{g}^{-1}$ at $65 \mathrm{gkg}^{-1} \mathrm{SOC}$. The slope of increase of MBC in response to increasing SOC was 2.5-fold higher in grassland at $27.2\left(\mu \mathrm{g} \mathrm{g}^{-1}\right) /\left(\mathrm{g} \mathrm{kg}^{-1}\right)$ compared to $10.7\left(\mu \mathrm{g} \mathrm{g}^{-1}\right) /\left(\mathrm{gkg}^{-1}\right)$ for cropland.

Zhang et al., (2016) revealed that Average annual SOC changes exhibited different responses to various climate change and management practice scenarios (Figs. 11a and 11b). Under the baseline scenario (CT), 2.32 Mha paddy soils increased $3.44 \mathrm{Tg} \mathrm{C}$ from 2001 to 2019 , with the annual SOC change of $78 \mathrm{~kg} \mathrm{C} \mathrm{ha}^{-1} \mathrm{yr}^{-1}$. This is mainly associated with the average chemical fertilizer application and farmyard manure incorporation rate of as high as $335 \mathrm{~kg} \mathrm{~N} \mathrm{ha}^{-1}$ $\mathrm{yr}^{-1}$ and $270 \mathrm{~kg} \mathrm{C} \mathrm{ha}^{-1} \mathrm{yr}^{-1}$, respectively. Applications of nutrients through fertilizers or organic manure increased crop yield and residue accumulation and thus large amount of organic matter is returned to the soil. In addition, SOC decomposition has been reduced in this region by utilizing no-tillage practices in wheat planting, which reduces the physical disturbance and increases the crop residues covered. The average annual SOC changes were -33 and $-330 \mathrm{~kg} \mathrm{Cha}^{-1} \mathrm{yr}^{-1}$ for the $0.5 \mathrm{FL}$ and NFL scenarios, respectively and the corresponding SOC changes are $142 \%$ and $522 \%$ lower than the baseline scenario.

In conclusions the SRs of SOC for 0-5:10 $15,15-20,20-25$ and $25-30 \mathrm{~cm}$ were all $>2$ under no-till-based treatments (NT-MWMB and NT-RWMB). However, the SRs under RT-RWMB and CT-RW were > 2 only below $20 \mathrm{~cm}$ soil depth, indicating a comparatively enhanced soil quality improvement under notill treatments. The storage of SOC $(0-30 \mathrm{~cm})$ was observed to be the highest under NTRWMB followed by NT-MWMB, RTRWMB and CT-RW. Furthermore, the storages of SOC were significantly related to the SRs of SOC along the soil profile. Hence, SR could be an indicator of SOC storage along the soil profile. The depth distribution of the storage of SOC also suggested $0-30 \mathrm{~cm}$ soil depth to be an adequate soil depth criterion for comparing SRs among conventional tillage-based agricultural practices and no-till-based CA practices.

The SOC, TN, POC and LOC contents of RP, $\mathrm{CK}$ and $\mathrm{AB}$ in soil layer of $100-200 \mathrm{~cm}$ were higher than SC, especially for RP plot. Although the SOC, TN, POC and LOC stocks in soil layer of $100-200 \mathrm{~cm}$ were lower, there was more than $27.38-36.62 \%, 25.10-32.91 \%$, $21.59-31.69 \%$ and $21.08-26.83 \%$ of SOC, $\mathrm{TN}, \mathrm{POC}$ and LOC stocks were distributed in $100-200 \mathrm{~cm}$ soil depth under RP, CK and AB. Meanwhile, the SR of SOC, TN, POC and LOC in the surface to lower depth ratio (i.e., $0-10: 10-40 \mathrm{~cm}$ ) was $>2.0$ in most of case. Changes in SOC concentration and composition occurred along with changes in structural stability to a depth of $15 \mathrm{~cm}$, consistent with a reduced capacity for tilled soil to physically protect organic matter from decomposition. Although differences in stability were evident from $15-28 \mathrm{~cm}$. SOC content in the surface soils under cropland (30 $\mathrm{gkg}^{-1}$ ) was significantly lower than $45 \mathrm{gkg}^{-1}$ under native vegetation land, as well as SON content (2.9 $\left.\mathrm{gkg}^{-1} / 4.4 \mathrm{gkg}^{-1}\right)$, macroaggregate proportion $(63 \% / 82 \%)$, and MWD $(0.73 \mathrm{~mm} / 0.94 \mathrm{~mm})$. Soil aggregation, soil aggregate stability, and SOC content in surface soils increased following agricultural abandonment. 
A significant effect of RT was sustained down to the $60-80 \mathrm{~cm}$ layer, while that of NT was sustained down to the $40-60 \mathrm{~cm}$ layer. This implies that conservation tillage can increase the SOC content in deep soil compared with CT. The RT treatment significantly increased the amount of small macro-aggregates in the layers from 10 to $100 \mathrm{~cm}$, and the number of small macro-aggregates in the $0-100 \mathrm{~cm}$ layers under NT was higher than under CT. In addition, the MWD and GMD under conservation tillage were higher than under CT at a soil depth of $0-80 \mathrm{~cm}$, which suggested a more stable aggregation with conservation tillage, not only in surface soil, but also in deep soil. The maximum enhancement effects were recorded in the minimum tillage along with residue retained treatment. Conventional tillage reduced soil organic $\mathrm{C}$ stocks and that of its labile fractions both in top and subsoil $(20-100 \mathrm{~cm})$. POC reduction was mainly driven by a decrease in fine POC in topsoil, while DOC was mainly reduced in subsoil. Fine POC, LFOC and microbial biomass can be useful early indicators of changes in topsoil organic C.

\section{References}

Ahmad, B., Amin, Z., Chabbert, B., Moorhead, D., Bertrand, I. 2014. Impact of fine litter chemistry on lignocellulolytic enzyme efficiency during decomposition of maize leaf and root in soil. Biogeochem., 117: 169183.

ÁlvaroFuentes J, Arrúe J L, Cantero-Martínez C, et al., 2008. Aggregate breakdown during tillage in a Mediterranean loamy soil. Soil Tillage Res., 101(1-2): 62-68.

Andruschkewitsch R, Koch H J, Ludwig B. 2014. Effect of long-term tillage treatments on the temporal dynamics of water-stable aggregates and on macroaggregate turnover at three German sites. Geoderma, 217-218: 57-64.

Angst G, John S, Mueller CW et al., 2016. Tracing the sources and spatial distribution of organic carbon in subsoils using a multi-biomarker approach. Nat Publ

Gr. https://doi.org/10.1038/srep 29478

Bu XL, Ruan HH, Wang LM, Ma WB, Ding JM, Yu XN. 2012. Soil organic matter in density fractions as related to vegetation changes along an altitude gradient in the Wuyi Mountains, southeastern China. Appl Soil Ecol. 52:42-7

Chatterjee N, Nair PKR, Chakraborty S, Nair VD. 2018. Agriculture, ecosystems and environment changes in soil carbon stocks across the forest-agro-forestagriculture/pasture continuum in various agro-ecological regions: a meta-analysis. Agric Ecosyst Environ 266:55-67.

Chen S, Xu C, Yan J, Zhang X, Zhang X, and Wang D. 2016. The influence of the type of crop residue on soil organic carbon fractions: An 11-year field study of rice-based cropping systems in southeast China. Agri Ecosyst Environ., 223:261-269.

Chen, S., Wang, W., Xu, W., and Wang, Y., et al., 2018. Plant diversity enhances productivity and soil carbon storage. PNAS, 115(16): 4027-4032.

Conforti, M., Luca, F., Scarciglia, F., Matteucci, G., and Buttafuoco, G. 2016. Soil carbon stock in relation to soil properties and landscape position in a forest ecosystem of southern Italy (Calabria region). Catena 144: 23-33

Davidson EA, Janssens IA. 2006. Temperature sensitivity of soil carbon decomposition and feedbacks to climate change. Nature. 440(7081):165-173.

Dhaliwal J, Kukal SS, Sharma S.2018.Soil organic carbon stock in relation to aggregate size and stability under tree 
based cropping systems in Typic Ustochrepts. Agroforestry Syst. 92(2): 275-284.

Devine S, Markewitz D, Hendrix P, Coleman D. 2014. Soil Aggregates and Associated Organic Matter under Conventional Tillage, No-Tillage, and Forest Succession after Three Decades. PLoS ONE 9(1): e84988. https://doi.org/10.1371/journal.pone.00 84988

Divya, P., Madhoolika, A., and Jitendra, S.B. 2014. Effects of conventional tillage and no tillage permutations on extracellular soil enzyme activities and microbial biomass under rice cultivation. Soil Tillage Res. 136: 5160.

Fujisaki K, Chapuis-Lardy L, Albrecht A et al., 2018. Data synthesis of carbon distribution in particle size fractions of tropical soils: implications for soil carbon storage potential in croplands. Geoderma 313:41-51.

Gu C, Liu Y, Mohamed I, Zhang R, Wang X, et al., 2017. Correction: Dynamic Changes of Soil Surface Organic Carbon under Different Mulching Practices in Citrus Orchards on Sloping Land. PLOS ONE 12(4): e0175600. https://doi.org/10.1371/journ al.pone.0175600

Hartmann C, Poss R, Noble A D, et al., 2008. Subsoil improvement in a tropical coarse textured soil: effect of deepripping and slotting. Soil Tillage Res, 99(2): 245-53.

Kong, A.Y.Y., and Six, J. 2010. Tracing root vs. residue carbon into soils from conventional and alternative cropping systems. Soil Sci. Soc. Am. J. 74: 1201-1210.

Liu, M., Guilin Han, G., and Zhang, Q. 2019. Effects of Soil Aggregate Stability on Soil Organic Carbon and Nitrogen under Land Use Change in an Erodible
Region in Southwest China. Int. J. Environ. Res. Public Health, 16: 2-14.

Liu S, Yan C, He W, et al., 2015. Effects of different tillage practices on soil waterstable aggregation and organic carbon distribution in dryland farming in northern China. Acta Ecologica Sinica, 35(4): 65-69.

Lynch, J.P., and Wojciechowski, T. 2015. Opportunities and challenges in the subsoil: pathways to deeper rooted crops. J. Exp. Bot. 66: 2199-2210.

Ma Z, Chen J, Lyu X, Liu Li-li, Siddique KHM. 2016. Distribution of soil carbon and grain yield of spring wheat under a permanent raised bed planting system in an arid area of northwest China. Soil Tillage Res.163: 274-281.

Mahajan, N.C., Kancheti Mrunalini, K.S. Krishna Prasad, K.S., Naresh, R.K., and Lingutla Sirisha. 2019. Soil Quality Indicators, Building Soil Organic Matter and Microbial Derived Inputs to Soil Organic Matter under Conservation Agriculture Ecosystem: A Review. Int. J. Curr. Microbiol. App. Sci. 8(2): 1859-1879.

Malviya, S.R. 2014. Effect of conservation agricultural practices on selected soil physical properties and carbon pools in black soils of central India. M.Sc. Thesis, Jawaharlal Nehru Krishi Vishwa Vidyalaya, Jabalpur, M. P.

Mangalassery, S., Sjogersten, S.,Sparkes, D.L., Sturrock, C.J., Craigon, J., and Mooney, S.J. 2014. To what extent can zero tillage lead to a reduction in greenhouse gas emissions from temperate soils? Sci Rep. 4: 4586. DOI: 10.1038/srep04586

McGonigle, T.P., and Turner, W.G. 2017. Grasslands and Croplands Have Different Microbial Biomass Carbon Levels per Unit of Soil Organic Carbon. Agriculture, 7, 57; doi:10.3390/ agriculture 7070057 
Nair, Pk Ramachandran, Vimala Nair, B. Mohan Kumar, and Julia M. Showalter. 2010. Carbon Sequestration in Agroforestry Systems. Report. Advances in Agronomy 108:237-307.

Naresh, R.K., Gupta, R.K., Vivek, Rathore, R.S., Singh, S.P., Kumar, A., Sunil Kumar, Sachan, D.K., Tomar, S.S., Mahajan, N.C., Lali Jat and Mayank Chaudhary. 2018. Carbon, Nitrogen Dynamics and Soil Organic Carbon Retention Potential after 18 Years by Different Land Uses and Nitrogen Management in RWCS under Typic Ustochrept Soil. Int. J. Curr. Microbiol. App. Sci. 7(12): 3376-3399.

Nath A J, Lal R. 2017. Effects of tillage practices and land use management on soil aggregates and soil organic carbon in the north Appalachian region, USA. Pedosphere, 27(1): 172-176.

Paustian, K., Lehmann, J., Ogle, S., Reay, D., Robertson, G.P., Smith, P. 2016. Climate smart soils. Nature 532: 49-57.

Patra, S., Stefan Julich, S., Feger, K.H., Jat, M.L., Sharma, P.C., and Schwärzel, K. 2018. Effect of conservation agriculture on stratification of soil organic matter under cereal-based cropping systems. Arch Agron Soil Sci., https://doi.org/10.1080/03650340.2019. 1588462

Plante AF, Fernandez JM, Haddix ML, Steinweg JM, Conant RT. 2011. Biological, chemical and thermal indices of soil organic matter stability in four grassland soils. Soil Biol Biochem. 43(5): 1051-8.

Poeplau C and Don A. 2013. Sensitivity of soil organic carbon stocks and fractions to different land-use changes across Europe. Geoderma 192:189-201.

Pulleman MM, Six J, van Breemen N, Jongmans AG. 2005. Soil organic matter distribution and microaggregate characteristics as affected by agricultural management and earthworm activity. Eur J Soil Sci. 56(4):453-67.

Rumpel, C., and Kögel-Knabner, I. 2011. Deep soil organic matter - a key but poorly understood component of terrestrial C cycle. Plant Soil 338: 143158.

Smith P, Fang CM, Dawson JJC, Moncrieff JB. 2008. Impact of Global Warming on Soil Organic Carbon. Adv Agron., 97:1-43.

Tripathi, R., Nayak, A.K., Bhattacharyya, P., Shukla, A.K., Shahid, M., Raja, R., Panda, B. B., Mohanty, S., Kumar, A., and Thilagam, A.K. 2014. Soil aggregation and distribution of carbon Wander, M.M., and Traina, S.J. 1996. Organic matter fractions from organically and conventionally managed soils. 1. Carbon and nitrogen distribution. Soil Sci. Soc. Am. J. 60: 1081-1087.

Wang Z, Liu GB, Xu MM. 2010. Effect of revegetation on soil organic carbon concentration in deep soil layers in the hilly Loess Plateau of China. Acta Ecologica Sinica 14: 3947-3952

Wang, H., Wang, S., Zhang, Y., Wang, X., Wang, R., and Li, J. 2018. Tillage system change affects soil organic carbon storage and benefits land restoration on loess soil in North China.

Wang, B., Gao, L., Yu, W., Wei, X., Li, J., Li, S., Song, X., Liang, G., Cai, D., and $\mathrm{Wu}, \mathrm{X}$. 2019. Distribution of soil aggregates and organic carbon in deep soil under long-term conservation tillage with residual retention in dryland. J Arid Land, 11(2): 241-254.

Wood SA, Sokol N, Bell CW et al., 2016. Opposing effects of different soil organic matter fractions on crop yields. Ecol Appl., 26: 2072-2085.

Yu, P., Liu, S., Ding, Z., Zhang, A., and Tang, X. 2020. Changes in Storage and 
the Stratification Ratio of Soil Organic Carbon under Different Vegetation Types in Northeastern China. Agronomy, $\quad 10, \quad 290$; doi:10.3390/agronomy10020290

Zhao, F.Z., Han, X.H., Yang, G.H., Feng, Y.Z., and Ren, G.X. 2014. Soil structure and carbon distribution in subsoil affected by vegetation restoration. Plant Soil Environ. 60(1): 21-26.

Zhao, F., Yang, G., Han, X., Feng, Y., and Ren, G. 2014. Stratification of Carbon Fractions and Carbon Management Index in Deep Soil Affected by the Grain-to- Green Program in China. PLoS ONE 9(6): e99657. doi:10.1371/journal.pone.0099657

Zhao X, Xue J-F, Zhang X-Q, Kong FL,Chen F, Lal R, et al., 2015. Stratification and Storage of Soil Organic Carbon and Nitrogen as Affected by Tillage Practices in the North China Plain. PLoS ONE, 10(6): e0128873. doi:10.1371/journal.pone. 0128873

Zhang, J., Bo, G., Zhang, Z., Kong, F., Wang, Y., and Shen, G. 2016. Effects of straw incorporation on soil nutrients, enzymes, and aggregate stability in tobacco fields of China. Sustainability.
8: 710- 721.

Zhong Z, Chen Z, Xu Y et al., 2018. Relationship between soil organic carbon stocks and clay content under different climatic conditions in Central China. Forests 9:1-14.

Zhou, M., Liu, C., Wang, J., et al., 2020. Soil aggregates stability and storage of soil organic carbon respond to cropping systems on Black Soils of Northeast China. Sci Rep., 10(1): 265. DOI: 10.1038/s41598-019-57193-1

Zhu G, Shangguan Z, Deng L. 2017. Soil aggregate stability and aggregateassociated carbon and nitrogen in natural restoration grassland and Chinese red pine plantation on the Loess Plateau. Catena, 149: 253-260.

Zou H, Ye X, Li J, Lu J, Fan Q, Yu N, et al., 2016. Effects of Straw Return in Deep Soils with Urea Addition on the Soil Organic Carbon Fractions in a SemiArid Temperate Cornfield. PLoS ONE 11

(4):

e0153214. doi:10.1371/journal.pone.0153214

Zotarelli L, Alves B, Urquiaga S, et al., 2007. Impact of tillage and crop rotation on light fraction and intra-aggregate soil organic matter in two Oxisols. Soil Tillage Res., 95(1-2): 196-206.

\section{How to cite this article:}

Singh, S. P., R. K. Naresh, Yogesh Kumar, Snehdeep and Rahul Inder Navsare. 2020. Variability in Soil Aggregation and Depth Distribution of Aggregate Associated Organic Carbon Fractions Relevance to Different Agricultural Practices in Agro-ecosystems of NorthWest India: A Review. Int.J.Curr.Microbiol.App.Sci. 9(09): 2780-2800. doi: https://doi.org/10.20546/ijcmas.2020.909.345 